\title{
Comet impact theory faces repeat analysis
}

Rex Dalton, San Diego

NASA is backing attempts to duplicate a published claim that a comet impact caused a mass extinction of species about 250 million years ago.

The space agency sent three scientists to China earlier this month to collect geological samples in an attempt to repeat the results of Luann Becker, a geochemist at the University of California, Santa Barbara, and her colleagues. Becker, whose research is funded by NASA, accompanied the group. The collected samples will be sent to ten laboratories for analysis early next year.

Deciphering the geochemical and seismic profiles of impacts millions of years ago that could have caused abrupt major changes in conditions on Earth is a highly contentious field. Inferences are drawn from geological samples taken around the globe, as researchers seek to identify impact craters that might be associated with a particular set of extinctions.

In 2001, Becker and her colleagues published an article reporting that the ratios of noble gases found in sediments in southern China were consistent with the theory that they originated in a comet or asteroid that hit Earth about 250 million years ago, at the boundary between the Permian and Triassic periods ${ }^{1}$. It is known that up to $90 \%$ of Earth's species were wiped out at around that time. But no one has yet duplicated Becker's results, which have now been disputed in correspondence to Science.

In 2003, Becker's group published another article ${ }^{2}$, which argued that pieces of meteorite found in Antarctica proved that

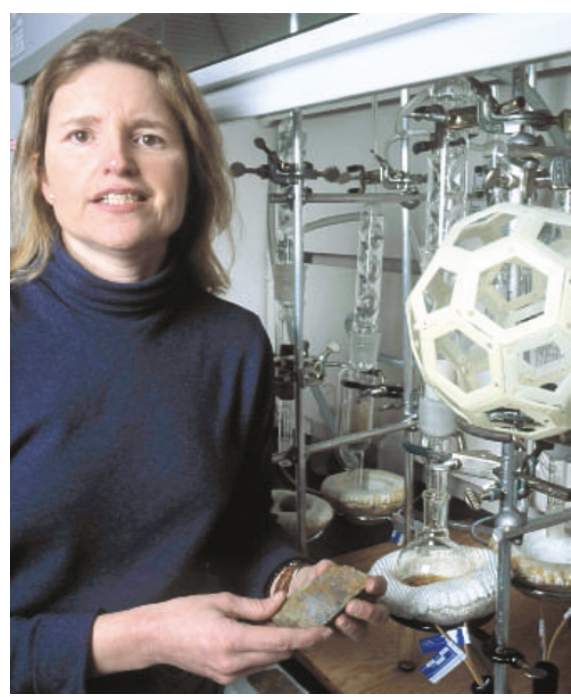

Luann Becker's claims that a comet caused mass extinctions $\mathbf{2 5 0}$ million years ago are disputed.

an asteroid impact had caused the Permian/ Triassic extinction. Other researchers have disputed that result, contending that the meteorite fragments in question are not as weathered as they should be for that age.

And last week Science published two letters $^{3,4}$ and a technical comment ${ }^{5}$ from Earth scientists criticizing a more recent article by Becker and her colleagues. That article located the asteroid's crater at a site off northwestern Australia ${ }^{6}$.

Jay Melosh, a geophysicist at the University of Arizona in Tucson and one of eight signatories to one of the letters in Science, says that the Becker group "have deeply muddied the waters about what is going on at the Permian/Triassic boundary".

But Becker says that she is looking forward to the new sample analyses for NASA, some of which she will conduct herself. She says her critics are being unreasonably aggressive. "This is science by intimidation," she says.

The critics say that they are driven by the lack of data backing up the original Becker papers. "They presented insufficient evidence of an impact crater or an age ascribed to it," says Paul Renne, a geochronologist at the University of California, Berkeley, and a signatory to the same letter to Science. "The latest Science paper undermines their credibility," says Renne, who argues that the data in the published paper do not support its conclusions. "A lot of researchers who were sceptical before are now sure Becker's group are wrong."

Michael New, a biophysicist who manages NASA's exobiology research programme, says that the agency learned earlier this year that some scientists were planning to do blinded studies that would repeat Becker's analysis of the Chinese samples, and decided to back it. The review is expected to cost about US\$100,000, with the results being published in mid-2005. "I thought it was a good idea to put together a consortium to figure out a consensus answer," he says.

1. Becker, L., Poreda, R. J., Hunt, A. G., Bunch, T. E. \& Rampino, M. Science 291, 1530-1533 (2001).

2. Basu, A. R., Petaev, M. I., Poreda, R. J., Jacobsen, S. B. \& Becker, L Science 302, 1388-1392 (2003).

Wignall, P., Thomas, B., Willink, R. \& Watling, J. Science 306, 609 (2004)

4. Renne, P. R. et al. Science 306, 610-611 (2004).

5. Glikson, A. Science 306, 613 (2004)

Becker, L. et al. Science 304, 1469-1476 (2004).

\section{Spain's budget fails basic science, researchers charge}

\section{Monica Salamone, Madrid}

Spanish researchers have lashed out at their new socialist government, accusing it of breaking pre-election pledges on science funding.

The government's first full budget since it came to power in March was released late last month - and researchers claim that it fails to deliver the major increase in science spending promised earlier this year.

In the run-up to the election, the socialists, led by José Luis Rodríguez Zapatero, had pledged to double Spain's $€ 4$-billion (US\$5.1-billion) annual research and development budget by 2008 (see Nature 428,$592 ;$ 2004). As part of this, researchers had hoped that spending would increase by $25 \%$ in 2005 as a first step towards that goal.

But the 2005 budget will see funding for scientists in universities and government laboratories grow by just under $8 \%$.

Prime Minister Zapatero's budget -

which is subject to approval by parliament in December - would increase total research and development expenditure sharply.

But the bulk of this rise will go towards military work, including the development and testing of weapons systems. Scientists have called on the government to exclude the military component from its figures and to boost funding for civilian science and technology.

Much of the budget's increases consist of interest-free loans that will be made available mainly to businesses for their development work - something that won't help basic researchers.

"Companies or private foundations can ask for these loans, but how are we scientists going to do it? It doesn't make sense," complains Joan Guinovart, president of the Confederation of Spanish Scientific Societies.

Guinovart and other scientists signed a statement in February that called for more state support for science, which they had hoped the new government would implement. And researchers this month issued another one saying that they are "enormously worried" by the government's budget plan. "We want a $25 \%$ increase in direct funds to research done in universities and public research centres," says Guinovart.

For more news and analysis go to news@nature.com www.nature.com/news 